\title{
Population dynamics of Scomberomorus brasiliensis from a small-scale fishery off Southern Brazil
}

\author{
Paulo de Tarso da Cunha Chaves ${ }^{1, *}$, Pollyana Olbera Birnfeld ${ }^{1} \oplus$, André Martins Vaz-dos-Santos ${ }^{\circledR}$
}

\begin{abstract}
1 Universidade Federal do Paraná - Setor de Ciências Biológicas - Departamento de Zoologia (Avenida Coronel Francisco H. dos Santos, 100 Caixa Postal: 19031 - Centro Politécnico - Jardim das Américas- 81531-980 - Curitiba - PR - Brazil).

2 Universidade Federal do Paraná - Setor Palotina - Laboratório de Esclerocronologia (Rua Pioneiro, 2153 Jardim Dallas - Palotina 85950-000 - PR - Brazil).
\end{abstract}

*Corresponding author: ptchaves@ufpr.br

\section{Abstract}

Scomberomorus brasiliensis is the most important fish species of the small-scale fishery off the southwestern Atlantic north of the La Plata estuary. For management purposes, this study evaluated their reproductive biology, size, age and growth along the Paraná coast. Monthly samples (March 2018-June 2020) from the fishery comprised 933 specimens (413 males, 520 females), $210-779 \mathrm{~mm}$ fork length, corresponding to a size smaller than in the northern areas. It presented negative allometry ( $b=2.69159$, length-weight relationship). Specimens in all stages of maturity occurred during the study period, indicating spawning in the area from October to June, peaking from January to March. The gonad-length relationship was suitable to confirm this assessment. Individual fecundity varied between 34,484 and 390,786 oocytes. Maturity occurred at $\mathrm{L}_{50}=446.46 \mathrm{~mm}, \mathrm{t}_{50}=1.4$ years, and $\mathrm{L}_{100}=588.79 \mathrm{~mm}$, and $\mathrm{t}_{100}=2.3$ years. The growth parameters were $\mathrm{L}^{\infty}=771.68 \mathrm{~mm}$, $k=0.65$ year $^{-1}$ and $t_{0}=-0.102$ years, with cohorts aged from 0.5 to 6.5 years. Scomberomorus brasiliensis along the Paraná coast constitutes a self-sustaining group, not directly related to that from northeastern Brazil. This small-scale fishery is not currently negatively affecting stock level; it is essential to monitor these attributes to detect future changes or impacts.

Descriptors: Reproductive biology, Growth, Artisanal, Management, Southwestern Atlantic.

\section{INTRODUCTION}

Scombridae fishes are important pelagic fishery resources worldwide, including large (>600 mm) and medium-sized (200 to $600 \mathrm{~mm}$ ) species (Fréon et al., 2005). Tunas are typical large-sized oceanic scombrids (Pons et al., 2017; Collette and Graves, 2019), and Scomber species are medium-sized neritic ones. Spanish mackerel, king mackerel and Brazilian Spanish mackerel are vernacular names for Scomberomorus spp., which is a

Submitted: 20-October-2020

Approved: 10-January-2021

Associate Editor: Francesc Maynou medium-sized species (sensu Fréon et al., 2005) widely distributed in neritic and coastal areas, including the east coast of South America (Froese and Pauly, 2019). Three species have been recorded in Brazil: S. regalis (Bloch 1793), S. cavalla (Cuvier, 1829), and S. brasiliensis Collette, Russo \& Zavala-Camin, 1978 (Figueiredo and Menezes, 2000; Fricke et al., 2020). Distributed from North and Central America, to South America, the southern limits of distribution of these species are different, $\sim 23^{\circ} 50^{\prime} S$ for $S$. regalis, $\sim 26^{\circ} 10^{\prime}$ S for S. cavalla, and $\sim 34^{\circ} \mathrm{S}$ for S. brasiliensis, which is the most abundant (Figueiredo and Menezes, 2000; Collette et al., 2011). Until the 1970s, S. brasiliensis was confused with S. maculatus (Mitchill, 1815), a species 
restricted to the east coast of North America and the Gulf of Mexico (FAO, 1983).

The Brazilian Spanish mackerel is an important fishery resource mainly for the small-scale (artisanal) fishery (Fonteles-Filho, 1988; Batista and Fabrè, 2001; Nóbrega et al., 2009; Collette et al., 2011). According to the last reliable Brazilian fishery statistic (IBAMA, 2007), it is one of the most valuable fishery resources, attaining above average prices for commercialization in the fish production chain. In 2007, 8,873 tons of Brazilian Spanish mackerel were landed, $99.7 \%$ from the small-scale fishery. Higher landings ( 94\%) occur in northern and northeastern Brazil ( $4^{\circ} 50^{\prime} \mathrm{N}$ to $\left.\sim 13^{\circ} \mathrm{S}\right)$, where S. brasiliensis is called "serra" in Portuguese and is targeted by a specific gillnet named "serreira" (Maia et al., 2015). In the southwestern Atlantic ( $\left.22^{\circ} \mathrm{S}-34^{\circ} \mathrm{S}\right)$, it is named "sororoca" in Portuguese and 462 tons were landed in 2007 (IBAMA, 2007). From 2009 to 2011, the average annual production of 433.9 tons was an underestimated value (MPA, 2011) due to the progressive dismantling of fishery statistics promoted by deficient federal policies. There have been no national fishery statistics in Brazil since 2012; however, from 2016 this situation changed in some parts of southern Brazil owing to the commencement of the Fisheries Activity Monitoring Project. This project was demanded by an environmental agency (IBAMA) to the Petrobras oil company and was undertaken by researchers from diferent institutions. This project has provided a reliable source of data from both industrial and small-scale fisheries in the area between $22^{\circ} \mathrm{S}$ and $29^{\circ} \mathrm{S}$.

The small-scale fishery is a common and well-developed activity throughout the Brazilian coast and is sometimes neglected and the victim of deficient policies similar to other fishery activities in Brazil (Oliveira and Silva, 2012; Isaac et al., 2013). Its importance is highlighted in the estuarine complexes and adjacent areas of the tropical and subtropical regions, including the Paraná coast (Chaves and Robert, 2003; Chaves and Silva, 2019). It is relatively short ( $100 \mathrm{~km}$ in a straight line); however, it plays a significant role in fish populations, providing areas for reproduction, feeding, and growth, highlighting the Paranaguá Estuarine Complex and the Guaratuba Bay (Andriguetto-Filho et al., 2006; Lana and Bernardino, 2018).

The Paraná coast only presents a small-scale fishery (Andriguetto-Filho et al., 2006), comprising approximately 5,000 artisanal fishers and an average landing of 2,573 tons per year (2017-2019) (PMAP, 2020). These recent data improved the previous lack of information reported by different authors (IBAMA/CEPSUL, 2000; Robert and Chaves, 2006; Mendonça and Miranda, 2008; Mendonça and Lucena, 2014; Chaves and Silva, 2019), and confirmed the importance of $S$. brasiliensis in the small-scale fishery of Paraná. During 2017-2019, the Brazilian Spanish mackerel occupied the third prodution position, with an average of 113 tons per year, after the shrimp Xiphopennaeus kroyeri (first) and the molusk Anomalocardia flexuosa (second) (PMAP, 2020). Although it is landed the year-round, both as a target species and as by-catch (Chaves and Silva, 2019), higher frequencies are recorded during warmer months (October to March) (UNIVALI, 2013).

Despite the importance of S. brasiliensis, the amount and focus of available studies on its fishery and biology are heterogeneous. This species has been well studied in northeastern Brazil, where there is a single stock (Nóbrega et al., 2009; Isaac et al., 2013); however, in southern Brazil ( $\left.22^{\circ} \mathrm{S}-34^{\circ} \mathrm{S}\right)$, including the Paraná coast, there are no studies. The species does not perform remarkable migrations like tunas, undergoing only seasonal and reproductive displacements (Collette et al., 1978, 2011; Batista and Fabrè, 2001). Therefore, it is reasonable that the individuals along the Paraná coast and adjacent areas caught by the small-scale fishery constitute a self-sustaining group (stock) not directly related to that from northeastern Brazil. Cadrin et al. (2014) defined stock as "an exploited fishery unit. A stock may be a single spawning component, a biological population, a metapopulation, or comprise portions of these units. For management purposes stocks are considered discrete units, and each stock can be exploited independently or catches can be assigned to the stock of origin". Thus, patterns of size, age, and growth (Ximenes, 1981; Nóbrega and Lessa, 2009), reproductive biology (Silva et al., 2005; Lima et al., 2007; Lima et al., 2009), feeding (Menezes, 1970; Fonteles-Filho, 1988; Lopes et al., 2016), parasites (Alves and Luque, 2006; Eiras et al., 2014), and fisheries and management (Almeida et al., 2007; Brito and Furtado Júnior, 2010; Leão et al., 2018) described for this species in other areas cannot be assumed the same for management purposes along the Paraná coast (Moksness et al., 2013; Cadrin et al., 2014). 
Considering this scenario, it is possible to establish the following premises: (i) S. brasiliensis is the most important fish species for the small-scale fishery along the Paraná coast; (ii) the small-scale fishery is an important, essential and complex activity whose management requires relevant information regarding fisheries resources; and (iii) population dynamics parameters are intrisic for each stock and subsidisize proper management measures. Therefore, the present study aimed to estimate the population parameters of $S$. brasiliensis along the Paraná coast, verifying which population component was accessed by the fishing activity. Techniques for investigating reproductive biology, size, age and growth were applied, considering the hypothesis that the self-sustaining group along the Paraná coast had its own biological patterns.

\section{METHODS}

\section{SAMPLING AND DATA ACQUISITION}

Scomberomorus brasiliensis samples were obtained from small-scale fishery landings at the Fishery Market of Matinhos (FMM), Paraná coast, southern Brazil ( $\left.25^{\circ} 49^{\prime} \mathrm{S}, 48^{\circ} 32^{\prime} \mathrm{W}\right)$ (Figure 1). Catches

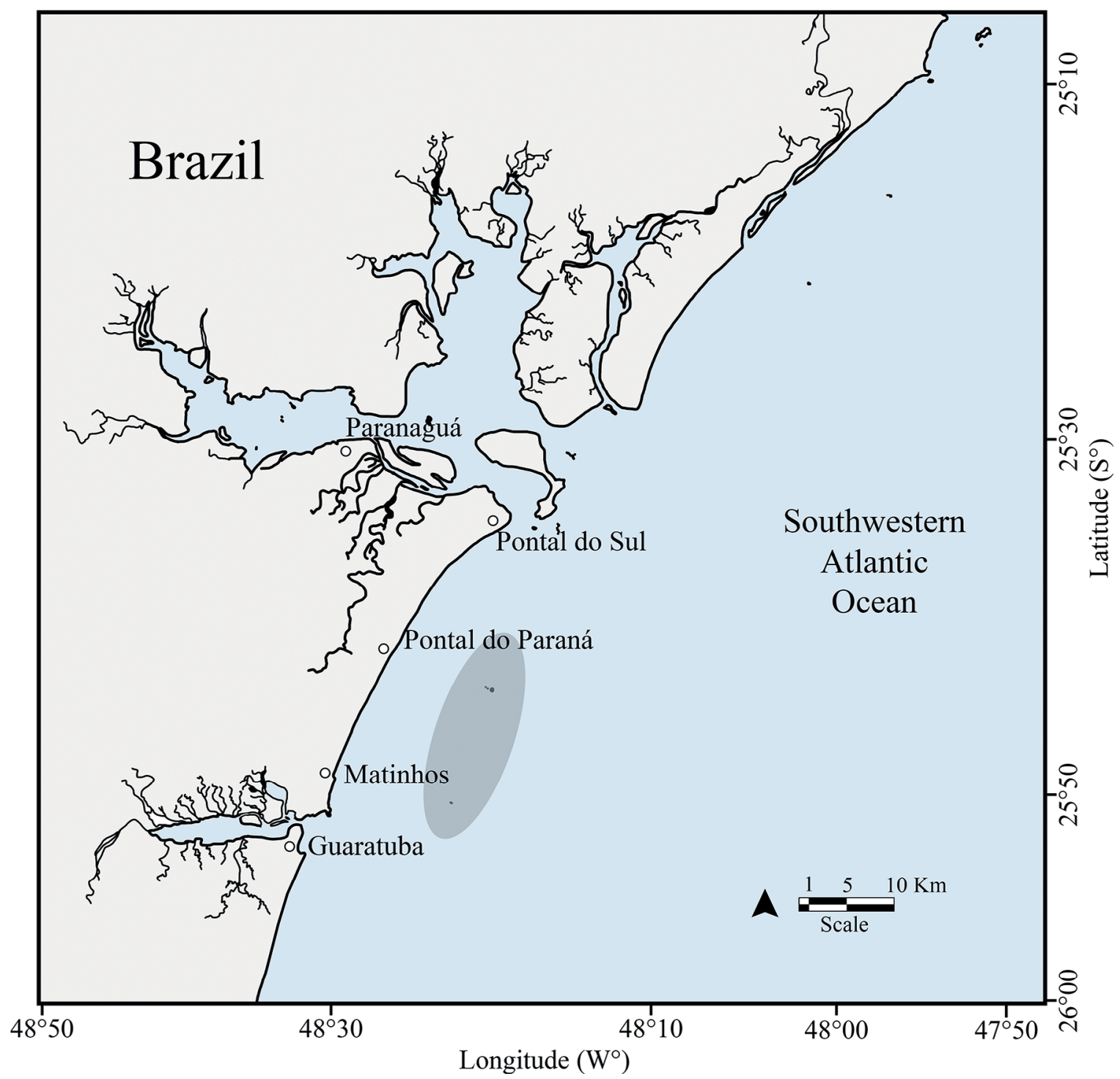

Figure 1. Paraná coast (southern Brazil) showing Matinhos (fishery landing site), Paranaguá Estuarine Complex and Guaratuba Bay. In grey the main fishing area of Scomberomorus brasiliensis by small-scale fishery. 
usually occurred with gillnets of varying mesh sizes (from $50 \mathrm{~mm}$ to $400 \mathrm{~mm}$, usually $70 \mathrm{~mm}$ to $170 \mathrm{~mm}$ mesh), 2-3.5 km of extension, varied soak time (usually 20-30 h), with local modalities named "fundeio" and "caceio" in Portuguese (Chaves and Robert, 2003; Andriguetto et al., 2006; Afonso and Chaves, 2021). FMM is the centre of the landings and processing of fishery resources in coastal adjacent areas up to $40 \mathrm{~m}$ in depth. As a gross estimate, fishing occurs in a surface area of $2,000 \mathrm{~km}^{2}$ and a volume of $40,000 \mathrm{~km}^{3}$ of the neritic region, corresponding to the inner continental shelf. The inner shelf is characterized by the coastal water, a water mass with salinities less than 35 and varying temperatures, limited by the bottom temperature boundary, an intersection between the mixed coastal waters and subsurface cold-water intrusions $\left(<18^{\circ} \mathrm{C}\right)$ that seasonally occur at the mid and outer shelf (Piola et al., 2018). During the study period, the atmospheric temperature in this region varied from $10.0^{\circ} \mathrm{C}$ (August 2019) to $38.5^{\circ} \mathrm{C}$ (January 2020) (DHN/Marinha do Brasil, 2021). The average values of sea surface temperature are available in the Supplementary Material, characterizing the seasons (summer = January, February, and March; autumn $=$ April, May, and June; winter = July, August, and September; and spring = October, November, and December).

Biological samples were obtained monthly at FMM from March 2018 to June 2020, comprising biometry and gonads of 933 S. brasiliensis specimens (Table 1), with limited numbers in some months due to non-capture. Specimens were measured for total length $(T L, m m)$ and fork length $(F L, m m)$ and, whenever possible, total weight (TW, g) depending on immediate filleting. Sex (male and female) and maturity were identified based on visual inspection of the gonads (Vazzoler, 1996; Brown-Peterson et al., 2011) as follows: immature (A), developing (B), spawning capable $(C)$, spawning capable with preovulatory hydration (Ch) only for females, and regressing (D). Morphological details of gonad features in each developmental phase are described in the Supplementary Material. From December 2018, gonad weight $(G W, g)$ was recorded.

For fecundity estimates, between December 2018 and February 2019 the left and right ovaries of 42 individuals, previously fixed in 10\% formalin, were separated and weighed, and a medial, small portion of each was obtained and weighed too. The two dry portions were mechanically dissociated, aiming to identify, under a steromicroscope, the vitellogenic oocytes recognized by their opacity, resulting from yolk deposition (Vazzoler, 1996; Brown-Peterson et al., 2011). The opaque oocytes were counted, and the number found in each portion was extrapolated for the total ovary weight. The total number of oocytes in both ovaries was summed, constituting the individual fecundity $\left(F_{i}\right)$.

Table 1. Scomberomorus brasiliensis: number of individuals $(\mathrm{N})$, range of fork length $(\mathrm{FL}, \mathrm{mm})$ by sex and month landed at Fishery Market of Matinhos, southern Brazil (zero indicates no samples available due to non-capture).

\begin{tabular}{|c|c|c|c|c|c|c|c|c|c|c|c|c|}
\hline & \multicolumn{4}{|c|}{2018} & \multicolumn{4}{|c|}{2019} & \multicolumn{4}{|c|}{2020} \\
\hline & \multicolumn{2}{|c|}{ Males } & \multicolumn{2}{|c|}{ Females } & \multicolumn{2}{|c|}{ Males } & \multicolumn{2}{|c|}{ Females } & \multicolumn{2}{|c|}{ Males } & \multicolumn{2}{|c|}{ Females } \\
\hline & $\mathrm{N}$ & FL range & $\mathrm{N}$ & FL range & $\mathrm{N}$ & FL range & $\mathrm{N}$ & FL range & $\mathrm{N}$ & FL range & $\mathrm{N}$ & FL range \\
\hline January & & & & & 2 & $546-558$ & 33 & $558-718$ & 30 & $450-530$ & 22 & $470-570$ \\
\hline February & & & & & 2 & $460-500$ & 10 & $500-670$ & 6 & $440-570$ & 8 & $480-580$ \\
\hline March & 33 & $310-510$ & 36 & $282-555$ & 0 & - & 0 & - & 20 & $210-570$ & 19 & $490-570$ \\
\hline April & 20 & $420-550$ & 14 & $480-550$ & 5 & $320-510$ & 3 & $460-710$ & 18 & $370-540$ & 22 & $480-600$ \\
\hline May & 10 & $514-600$ & 13 & $545-673$ & 0 & - & 0 & - & 29 & $490-600$ & 6 & $460-600$ \\
\hline June & 11 & $462-560$ & 7 & $479-571$ & 23 & $400-701$ & 25 & $440-730$ & 13 & $550-610$ & 29 & $510-630$ \\
\hline July & 36 & $497-617$ & 36 & $479-778$ & 21 & $430-740$ & 49 & $440-690$ & & & & \\
\hline August & 10 & $576-692$ & 10 & $582-667$ & 10 & $480-680$ & 37 & $430-660$ & & & & \\
\hline September & 0 & - & 0 & - & 17 & $430-670$ & 34 & $400-710$ & & & & \\
\hline October & 0 & - & 0 & - & 21 & $440-600$ & 26 & $400-760$ & & & & \\
\hline November & 0 & - & 0 & - & 34 & $460-630$ & 26 & $450-660$ & & & & \\
\hline December & 18 & $510-693$ & 22 & $485-779$ & 24 & $420-570$ & 33 & $430-610$ & & & & \\
\hline
\end{tabular}




\section{Data ANALYSIS}

The results are presented based on FL data. Regressions between TL and FL were fitted for males and females together and separate, allowing for conversions. Linear models were adjusted by the iterative least squares method with the LevenbergMarquardt algorithm and 9,999 iterations (Motulsky and Christopoulos, 2003). Residual analysis was performed and outliers ( $|Z|>1.96)$ were removed. The models were re-adjusted, and regressions for each sex were compared with an analysis of covariance (Zar, 2010). The length-weight relationship was fitted for males and females together (Froese, 2006), and using the iterative method. A $t$-test was applied to verify the isometric pattern $(\beta=3)$ of the coefficient $b$ value. All statistical procedures were performed with $a=0.05$.

The spawning period was verified based on the overall monthly distribution of gonad developmental phases (Lowerre-Barbieri et al., 2011). For a detailed diagnosis, monthly frequencies of females and males in reproductive activity (combined frequency of $\mathrm{C}+\mathrm{Ch}+\mathrm{D})$ were tested using a heterogeneity chisquare test (Zar, 2010). The gonad-length relationship (GLR $=$ GW / FL × 100) was individually estimated from December 2018, helping the spawning period diagnostic. Because of the GLR dependence on FL, the size effect was removed by calculating $G L R^{\prime}=G L R$ $\times\left(\mathrm{FL}_{0} / \mathrm{FL}\right)^{b}$, where the reference values for standardization were $\mathrm{FL}_{0}=516.05 \mathrm{~mm}$ (average $\mathrm{FL}$ ), and $b=$ 3.0208 from the model GLR $=a \mathrm{FL}^{b}$ (Lombarte and Lleonart, 1993). Then, a confidence interval plot (95\% $t$-distribution) of GLR' values by sex and gonad developmental phase was created to ascertain the representativeness of gonad maturity. After checking, individual values were graphically analyzed: (i) a dotplot by sex, gonad maturity and month was used to investigate individual variations, and (ii) a confidence interval plot was used to analyze averages (excluding immature individuals) by sex and month. Monthly averages of GLR' were tested using a one-way analysis of variance, and assumptions were tested and confirmed in the residual analysis. The variance inflation factor was used to detect extreme averages with multicollearinity, considering a cut-off value of 5 (Zuur et al., 2009; Legendre and Legendre, 2012). A post-hoc Tukey test was applied to detect differences among monthly averages.
Individual fecundity $(y)$ was evaluated by fitting linear models between FL and gonad weight $(x)$ by the aforementioned iterative method. The average length at first maturity $\left(L_{50}\right)$ was estimated based on a logistic model (Haddon, 2011), in which the frequencies of adult females $(P)$ were plotted against the bottom limit of length classes $(L)$ following the formula $P=1 /\left[1+\mathrm{e}_{50}^{-r(L-L)}\right]$. Previously, two approaches were verified: one considering $\mathrm{C}+\mathrm{Ch}+\mathrm{D}$ as adults, and the other with $B+C+C h+D$ as adults, the former being inadequate due to the mix between individuals for the first time as developing and reccurrent ones. The non-linear iterative least squares method with the Levenberg-Marquardt algorithm and 9,999 iterations was applied to fit the model (Motulsky and Christopoulos, 2003). Based on the model, the length at which all individuals could reproduce $\left(\mathrm{L}_{100}\right)$ was estimated.

The von Bertalanffy growth model (VBGM) parameters were estimated. After simulations, the maximum theoretical length $\left(L_{\infty}\right)$ was calculated using the Powell-Wetherall method and the growth rate $(k)$ with the Shepherd length composition analysis (SLCA) (Isaac, 1990), considering fine adjustments in the routine introduced by Gayanilo et al. (2005). The theoretical age at zero length $\left(\mathrm{t}_{0}\right)$ was estimated using the Pauly formula (Pauly, 1984). The instantaneous growth rate $\left(G=\left[\left(\ln F_{2}-\ln F_{1}\right) /\left(t_{2}-t_{1}\right)\right] \times 100\right)$ was calculated, and for age zero approximated values were $\mathrm{FL}_{1}=5 \mathrm{~mm}$ (based on Jenkins et al., 1984; Shoji et al., 2002) and $t_{2}=0.5$ years. Based on the growth parameters, an inverse VBGM was used to estimate the average age at first maturity $\left(t_{50}\right)$ and the age at which all individuals could reproduce $\left(t_{100}\right)$.

\section{RESULTS}

The 933 individuals of $S$. brasiliensis comprised 413 males (range of 210-740 mm FL), and $520 \mathrm{fe}-$ males (range of 282-779 $\mathrm{mm} \mathrm{FL)} \mathrm{(Table} \mathrm{1).} \mathrm{The} \mathrm{FL-}$ TL relationships did not show significant differences between males and females ( $F=0.88 ; p=0.35)$, thus ensuring representativeness for the grouped model (Table 2). The length-weight relationship (Table 2, and Figure in the Supplementary Material) presented negative allometry $(t=-3.86 ; p=0.000172)$.

Specimens from all maturity stages were found, although with varying proportions during the study period. Juveniles (immature, A) of S. brasiliensis were 
Table 2. Scomberomorus brasiliensis: summary of regressions involving total length (TL), fork length (FL), weight (TW), individual fecundity (Fi), gonad weight (GW), and proportion of adult females (P) for individuals landed at Fishery Market of Matinhos, southern Brazil, years 2018-2020 ( $a$ and $b$ - regression coefficients; in the logistic model $r=a$ and $L_{50}=b$, $\mathrm{SE}$ - standard error, $\mathrm{N}$ - number of data, $\mathrm{F}$ - regression statistics, $p$ - probability, $\mathrm{r}^{2}$ - coefficient of determination).

\begin{tabular}{|c|c|c|c|c|c|c|c|c|}
\hline Model & $a$ & $\mathrm{SE}_{a}$ & $\boldsymbol{b}$ & $\mathrm{SE}_{b}$ & $\mathbf{n}$ & $\mathbf{F}$ & $p$ & $\mathbf{r}^{2}$ \\
\hline \multicolumn{9}{|l|}{$\mathrm{FL}=\mathrm{a}+\mathrm{b} \mathrm{TL}$} \\
\hline males+females & -13.17 & 3.56 & 0.87805 & 0.00587 & 674 & 22393.55 & $<0.001$ & 0.971 \\
\hline males & -10.03 & 5.09 & 0.87339 & 0.00863 & 288 & 10247.27 & $<0.001$ & 0.973 \\
\hline females & -17.14 & 5.14 & 0.88399 & 0.00832 & 387 & 11293.90 & $<0.001$ & 0.967 \\
\hline $\mathrm{TW}=a \mathrm{FL}^{b}$ & 0.0000537775 & 0.0000275 & 2.69159 & 0.0798774 & 49 & 91.55 & $<0.001$ & 0.971 \\
\hline $\mathrm{Fi}=a+b \mathrm{FL}$ & $-806,174.00$ & $129,607.00$ & $1,784.00$ & 246 & 38 & 52.63 & $<0.001$ & 0.594 \\
\hline $\mathrm{Fi}=a+b \mathrm{GW}$ & $-13,803.00$ & $10,572.00$ & $5,385.00$ & 352 & 39 & 234.61 & $<0.001$ & 0.864 \\
\hline $\mathrm{P}=1 /\left[1+\mathrm{e}^{-\mathrm{r}}\left(\mathrm{L}-\mathrm{L}{ }_{50}\right)\right]$ & 0.03229 & 0.00439 & 446.47 & 4.470 & 13 & 54.63 & $<0.001$ & -- \\
\hline
\end{tabular}

constant and frequent between June and October 2019 (autumn and winter). Individuals in the developing (B) phase occurred in all months of the year, and from April (beginning of autumn) and August (winter) their frequencies were higher than $30 \%$ over the two years (Figure 2).

Scomberomorus brasiliensis specimens in reproductive activity $(\mathrm{C}+\mathrm{Ch}+\mathrm{D})$ presented more than $30 \%$ of the frequency between November and December (end of spring) up to February 2019 (summer) and June 2020 (winter) (Figure $3 a)$. There were differences between sexes and years $\left(X^{2}=50.30, p=2.65 \times 10^{-6}\right)$ due to the predominance of females. This predominance was remarkable in January $2019\left(X^{2}=24.40\right.$, $\left.p=7.43 \times 10^{-7}\right)$, April $2019\left(x^{2}=4.00, p=0.0455\right)$, January $2020\left(X^{2}=7.20, p=0.0073\right)$, April $2020\left(X^{2}=15.21, p=9.61 \times 10^{-5}\right)$ and June $2020\left(X^{2}=14.23, p=0.0002\right)$, evidencing a reccurrent pattern. Detailing the frequency of females, during the summer of 2019 and summer-autumn of 2020 there was a gradual decrease of spawning capable individuals $(\mathrm{C}+\mathrm{Ch})$ and an increase of regressing ones (D) (Figure $3 \mathrm{~b}$ ).

The gonad-length relationship (after size-effect removal) varied significantly among the gonad developmental phases (Figure 4 and referential values in the Supplementary Material). Higher individual values were recorded during the summer and autumn for both sexes (Figure $5 \mathrm{a}$ and $5 c$ ), related to reproductive activity. Average values of GLR' (Figure $5 b$ and $5 d$ ) presented significant variation among months for both females $(\mathrm{F}=13.78 ; p<0.001)$ and males $(\mathrm{F}=9.96 ; p<0.001)$. Increases in GLR' indicated periods of intense reproductive activity. Alternate patterns of increases and decreases presented differences ( $p<0.05$ from Tukey tests, cf. Supplementary Material), although sequential values of these "sets" of high and low values did not differ, indicating homogeneity during intense and non-intense periods of reproductive activity.

Individual fecundity varied between 34,484 (410 mm FL) and 390,786 oocytes $(650 \mathrm{~mm}$ $\mathrm{FL})$, progressively increasing in relation to $\mathrm{FL}$ and ovary weight (Figure 6 and Table 2). The first maturity corresponded to an average length of $446.46 \mathrm{~mm}$ FL (Figure 7, Table 2), corresponding to $t_{50}=1.4$ years, and based on the model, $\mathrm{L}_{100}=588.79 \mathrm{~mm} \mathrm{FL}$ and $\mathrm{t}_{100}$ $=2.3$ years.

The estimated growth parameters were $\mathrm{L}_{\infty}=771.68 \mathrm{~mm}, k=0.65$ year $^{-1}$, and $\mathrm{t}_{0}=-0.102$ years (Figure 8). The score function plot revealed a single peak corresponding to the estimated $k$ value, ensuring its representativeness. Scomberomorus brasiliensis individuals presented ages from 0.5 to 6.5 years, predominating individuals of 1 year (32\%), 1.5 years (45\%) and 2 years (16\%). The instantaneous growth 
a

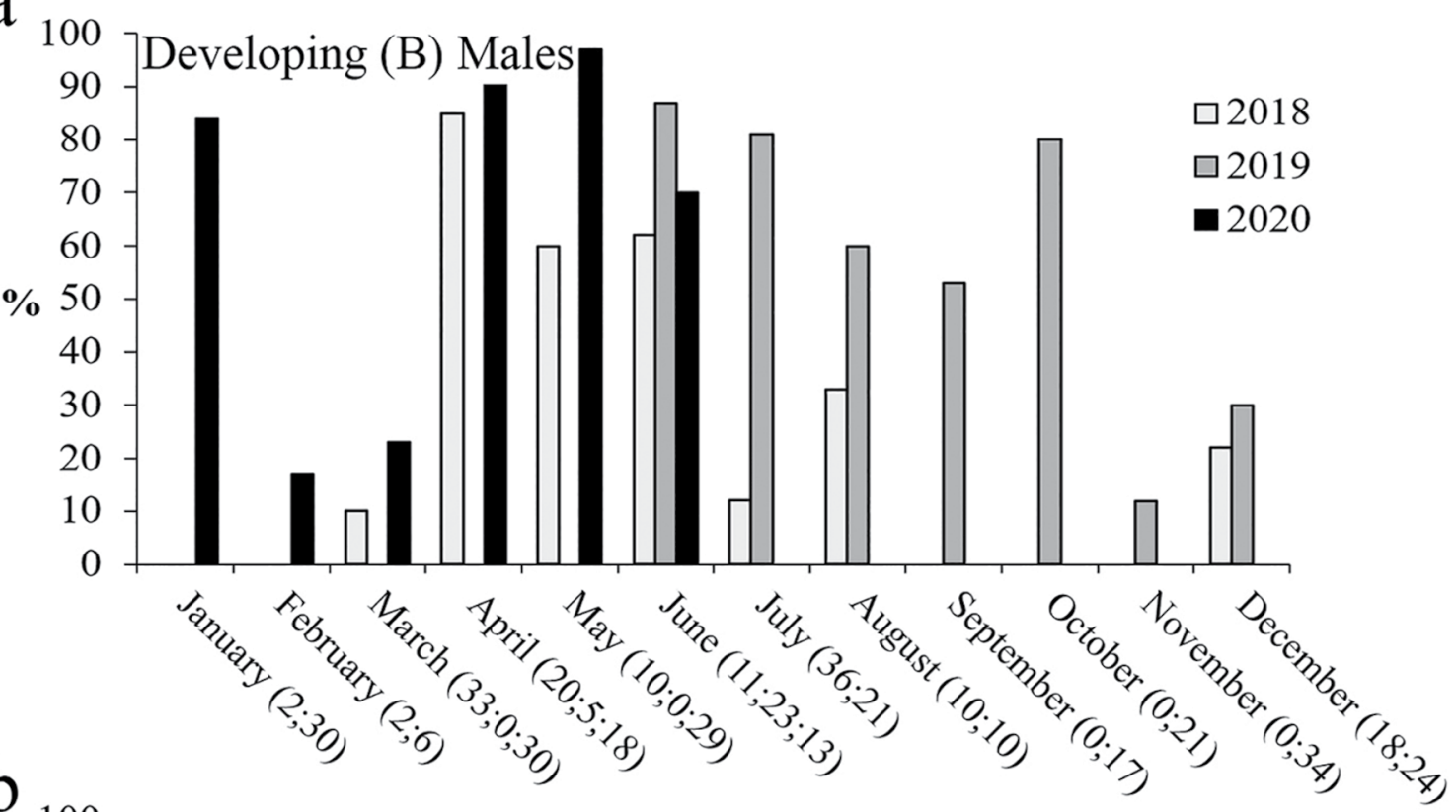

b

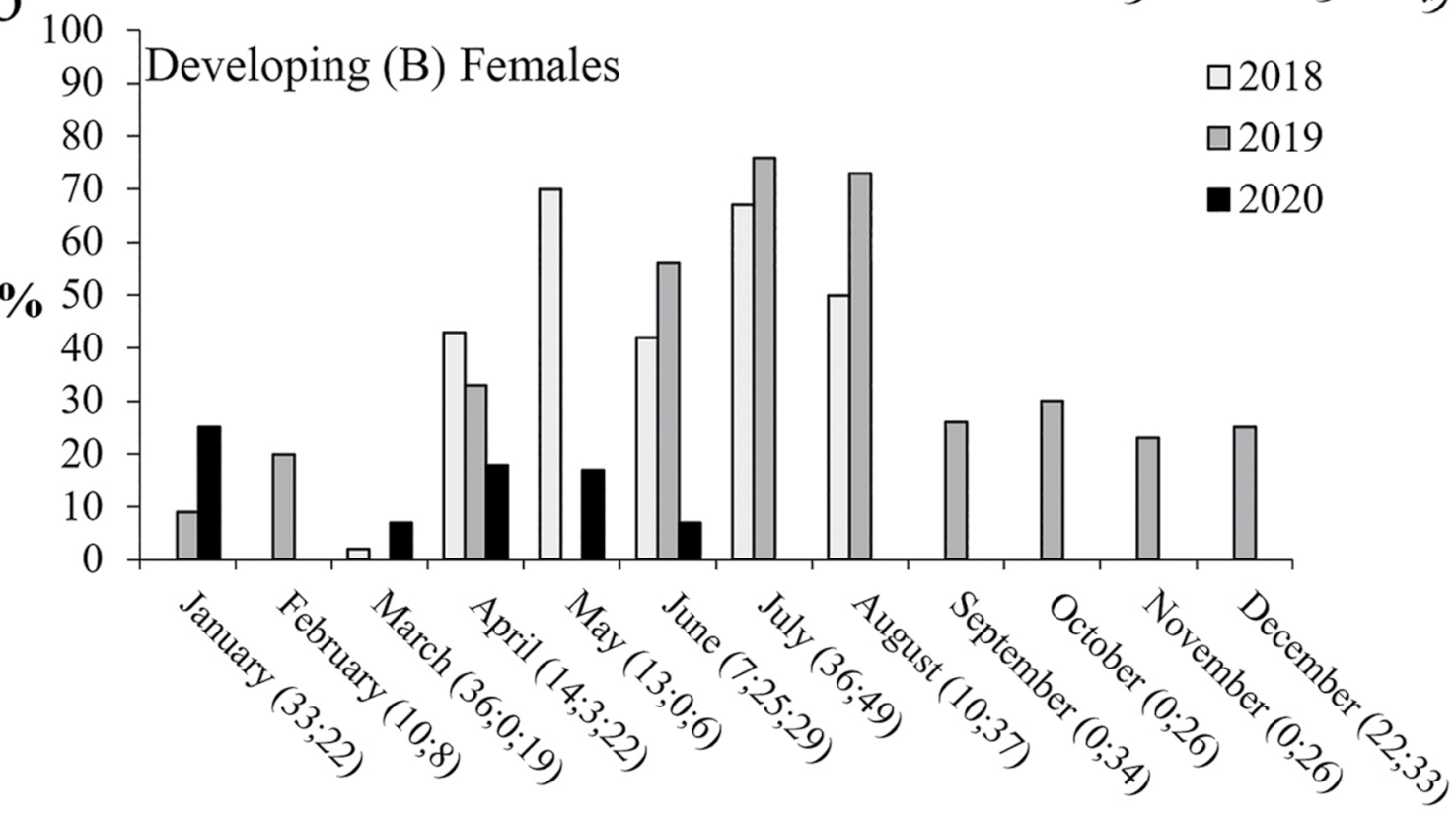

Figure 2. Scomberomorus brasiliensis: developing proportion of (a) males and (b) females (number of individuals by year into parenthesis, respectively).

rate evidenced a rapid growth up to 2.5 years, corresponding to $629 \mathrm{~mm} \mathrm{FL}$, which then decreased significantly (Figure 8).

\section{DISCUSSION}

Biological sampling of fish landings is crucial for understanding the population strata accessed by fishing activity, information that subsidizes stock assessment and proper management measures (Cadima et al., 2005; Murie et al., 2012). The practical sample unit in the present study was the FMM, the focal point of a small-scale fishery, and sampling effort comprised the size range available of $S$. brasiliensis, similar to the procedures described by Batista and 
a

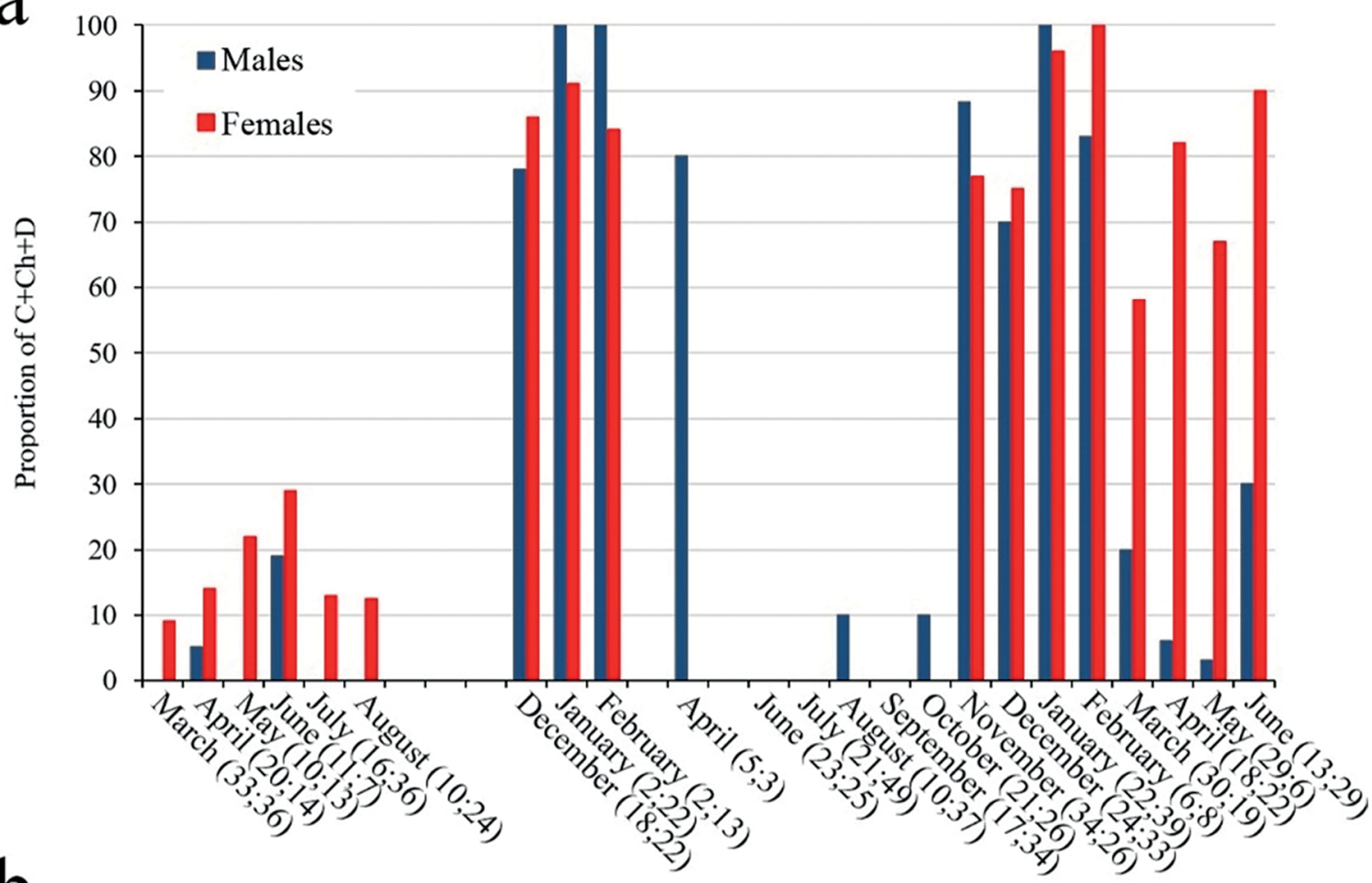

b

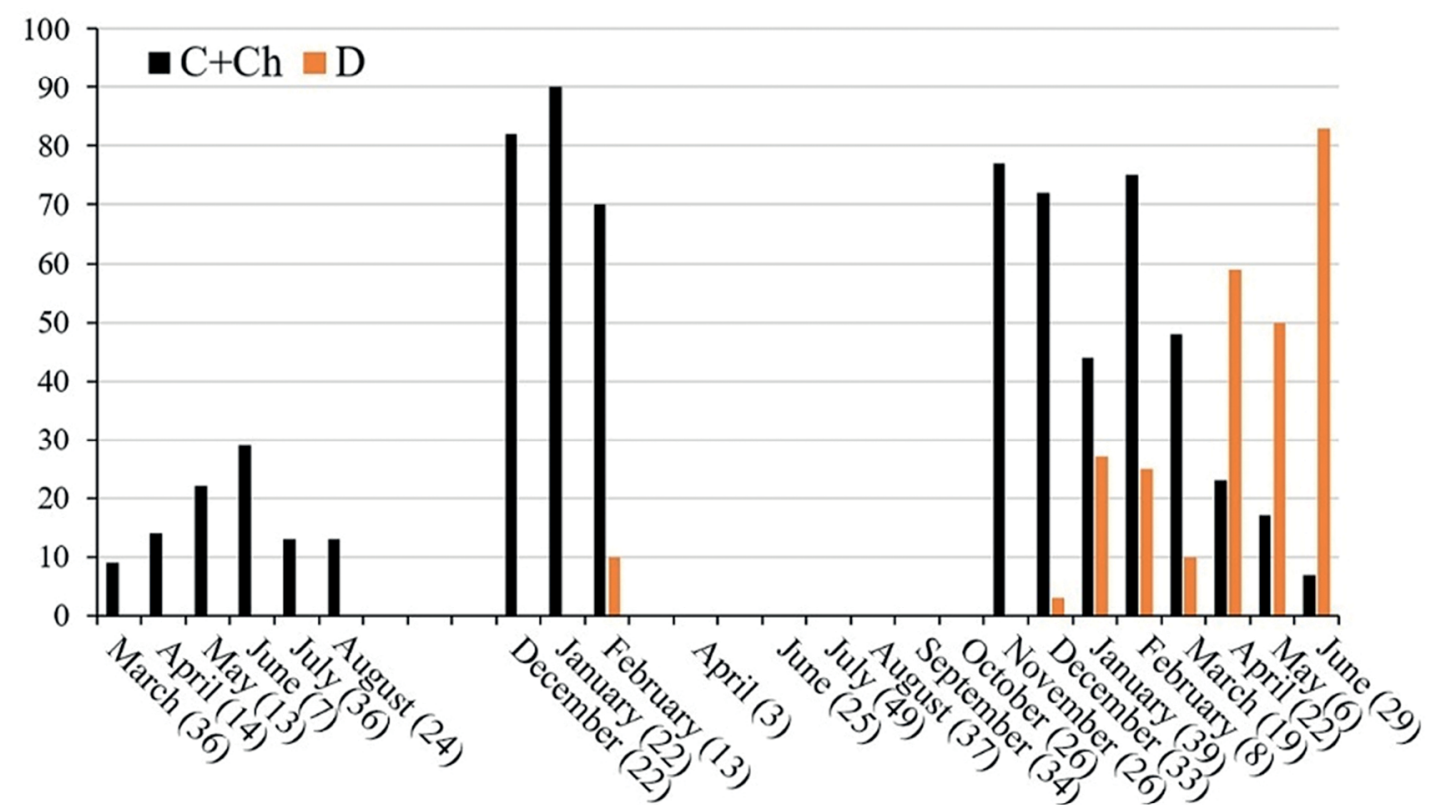

Figure 3. Scomberomorus brasiliensis: (a) monthly proportion of reproductive activity $(C+C h+D)$ individuals by sex (number of males and females into parenthesis, respectively), (b) monthly proportion of reproductive activity $(C+C h$ and $D)$ females (number of individuals into parenthesis) (no samples available from September to November 2018, nor in March and May 2019).

Fabrè (2001). Thus, the population parameters of $S$. brasiliensis along the Paraná coast were properly estimated, revealing that the small-scale fishery caught mainly adults at and just after the first maturity.
The range of observed FLs was influenced by gillnet selectivity, explaining the low incidence of individuals less than $300 \mathrm{~mm}$ FL and larger than $700 \mathrm{~mm}$ FL. In the Caribbean Sea and the northern 


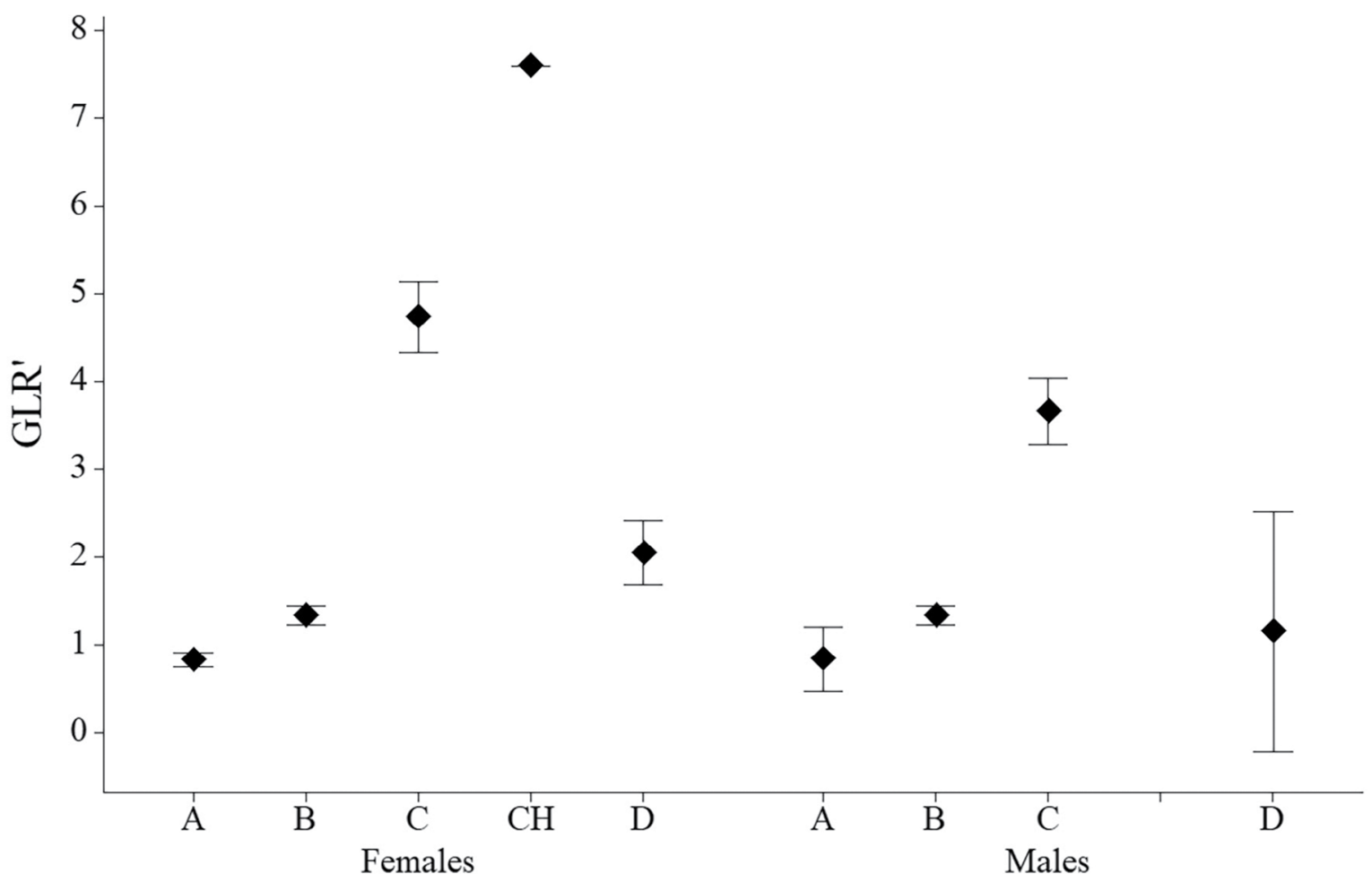

Figure 4. Scomberomorus brasiliensis: average values and confidence intervals ( $95 \% t$-distribution) of gonad-length relationship (GLR') by sex and gonad developmental phase.

and northeastern Brazil, maximum lengths recorded were larger than $900 \mathrm{~mm}$ FL (Froese and Pauly, 2019) and attained a $1360 \mathrm{~mm}$ FL (Nóbrega et al., 2009), which does not occur in the small-scale fishery of Paraná. These individuals either cannot occur at this latitude or are not accessed by the fishing activity. The former has support; otherwise, larger individuals would be common in other small-scale fisheries and in the industrial fishery that occurs in adjacent areas far from the coast, which has not happened either historically (Andriguetto et al., 2006; IBAMA, 2007) or recently (PMAP, 2020). However, S. brasiliensis along the Paraná coast is caught mainly by gillnets (Chaves and Robert, 2003), and 99\% came from this fishing gear during 2017-2019 (PMAP, 2020). Therefore, the samples in the present study well represented the adults of the area, in view of the different mesh sizes of gillnets and fishing gears used in the Paraná coast and adjacent areas (Andriguetto et al., 2006), even under selectivity effects (Hubert et al., 2012).

Size structure influences the sex-ratio. Data from the present study showed that $S$. brasiliensis females were larger than males, similar to that in northeastern
Brazil (Nóbrega and Lessa, 2009; Maia et al., 2015). This dimorphism was not evidenced in the relative growth pattern (FL-TL relationship), only in the predominance of females (0.8:1, males:females), which varied compared to other studies. In northeastern Brazil, in coastal areas between $04^{\circ} 39^{\prime} \mathrm{S}$ and $06^{\circ} 29^{\prime} \mathrm{S}$, the sex-ratios observed were 1.1:1 $(n=145)$ in a beach (from beach trawls) (Lima et al., 2007), and 2:1 (Oliveira et al., 2015), from joining samples from various beaches and omitting the number of individuals analyzed. The former represents a local proportion between males and females; however, the latter cannot be considered owing to the lack of information. In contrast, Nóbrega and Lessa (2009) found a sex ratio of 1.4:1, sampling a large area of the continental shelf $\left(02^{\circ} 30^{\prime} \mathrm{S}-13^{\circ} \mathrm{S}\right.$, macro-scale study), evidencing different patterns of $S$. brasiliensis from northeastern Brazil compared to the Paraná coast.

Length-weight relationships also present intrinsic patterns related to biological and methodological aspects (Froese, 2006). Biological aspects include stock-population identity and density-dependent processes related to population dynamics (McBride, 

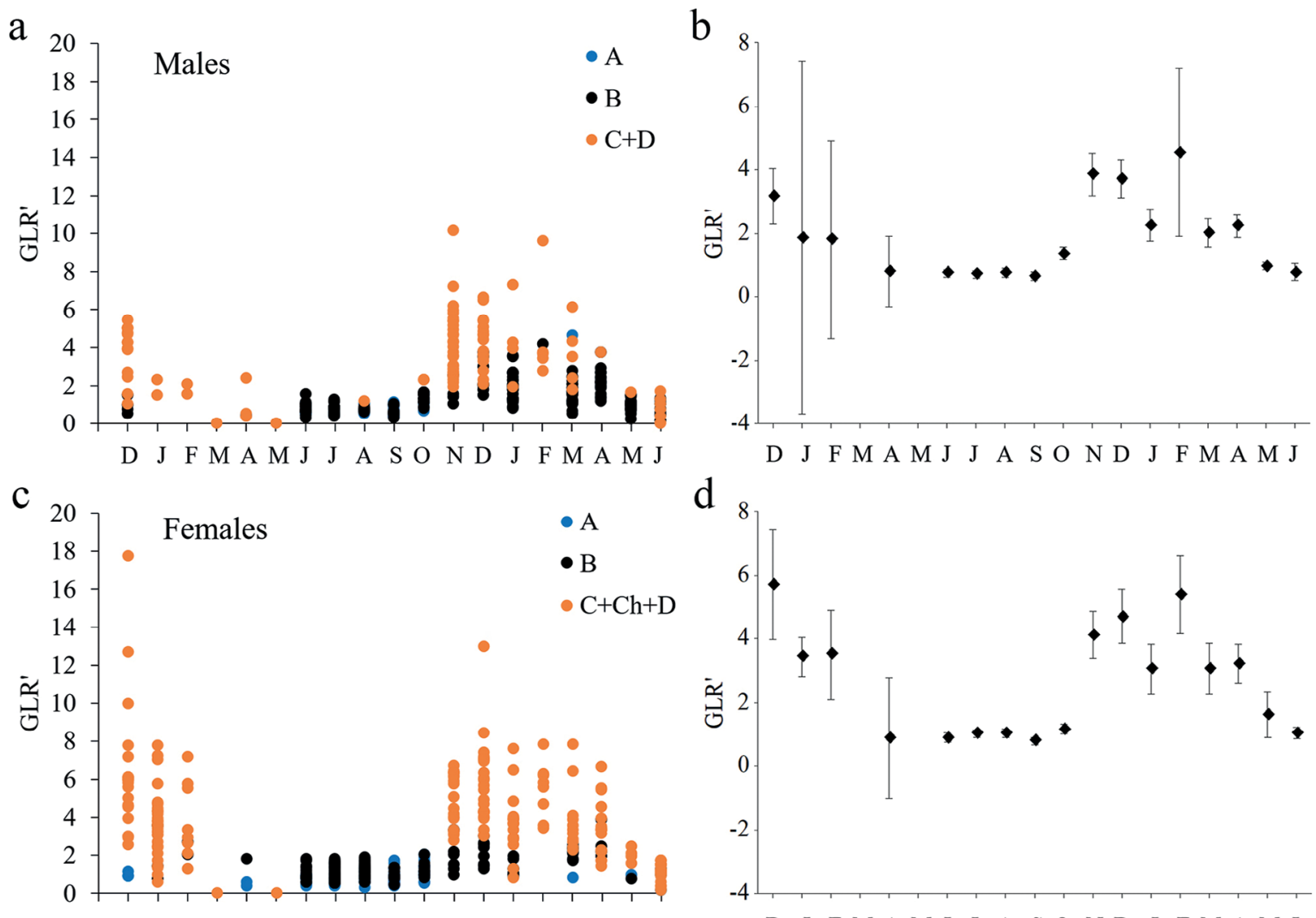

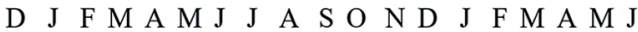

D $\quad$ J $\quad$ F M A M J J A

Figure 5. Scomberomorus brasiliensis: individual values of gonad-length relationship by gonad developmental phase for males (a) and females (c) and average values and confidence intervals ( $95 \% t$-distribution) of gonad-length relationship (GLR') for males (b) and females (d) excluding immature individuals.

2014). Methodological aspects are related to the size range analyzed, number of fishes, and model adjustments (i.e. algorithm used, linear vs. non-linear procedure, checking of assumptions). Thus, although direct comparisons among different studies require caution, some insights emerge. The $b$ coefficient of the Caribbean Sea and northeastern Brazil ranged between 2.800 and 3.264, mean $2.97(n=9)$ (Silva et al., 2005; Tagliafico et al., 2015; Froese and Pauly, 2019), suggesting a conservative pattern of negative allometry also detected in the present results. In $S$. brasiliensis, these $b$ values $(<3)$ were closely related to their elongated body shape, which predominates growth in length (Froese, 2006).

A remarkable diagnostic herein presented is the spawning of $S$. brasiliensis on the inner continental shelf of the Paraná coast, reinforcing the group identity in the area. In northeastern Brazil, there are two proposals, a high migratory pattern based on seasonal absences in some areas (Batista and Fabrè, 2001), and small-scale displacements in large areas (Colette et al., 2011). Both do not apply for the Paraná coast, where there is a continuous landing of individuals with $400-600 \mathrm{~mm}$ FL throughout the year, indicating the stock permanency in the area and small-scale fishery availability. Regarding the spawning period of $S$. brasiliensis on the Paraná coast (beginning in the spring, peaking in the summer, and finishing in the autumn), it was similar to historical records in northeastern Brazil (Gesteira and Mesquita, 1976). Nonetheless, more recent data from that area indicate spawning peaks in the summer and autumn (March to June), corresponding to the rainy season in that region (Lima et al., 2007) and matched with a higher abundance of S. brasiliensis (Brito and Furtado Júnior, 2010). 

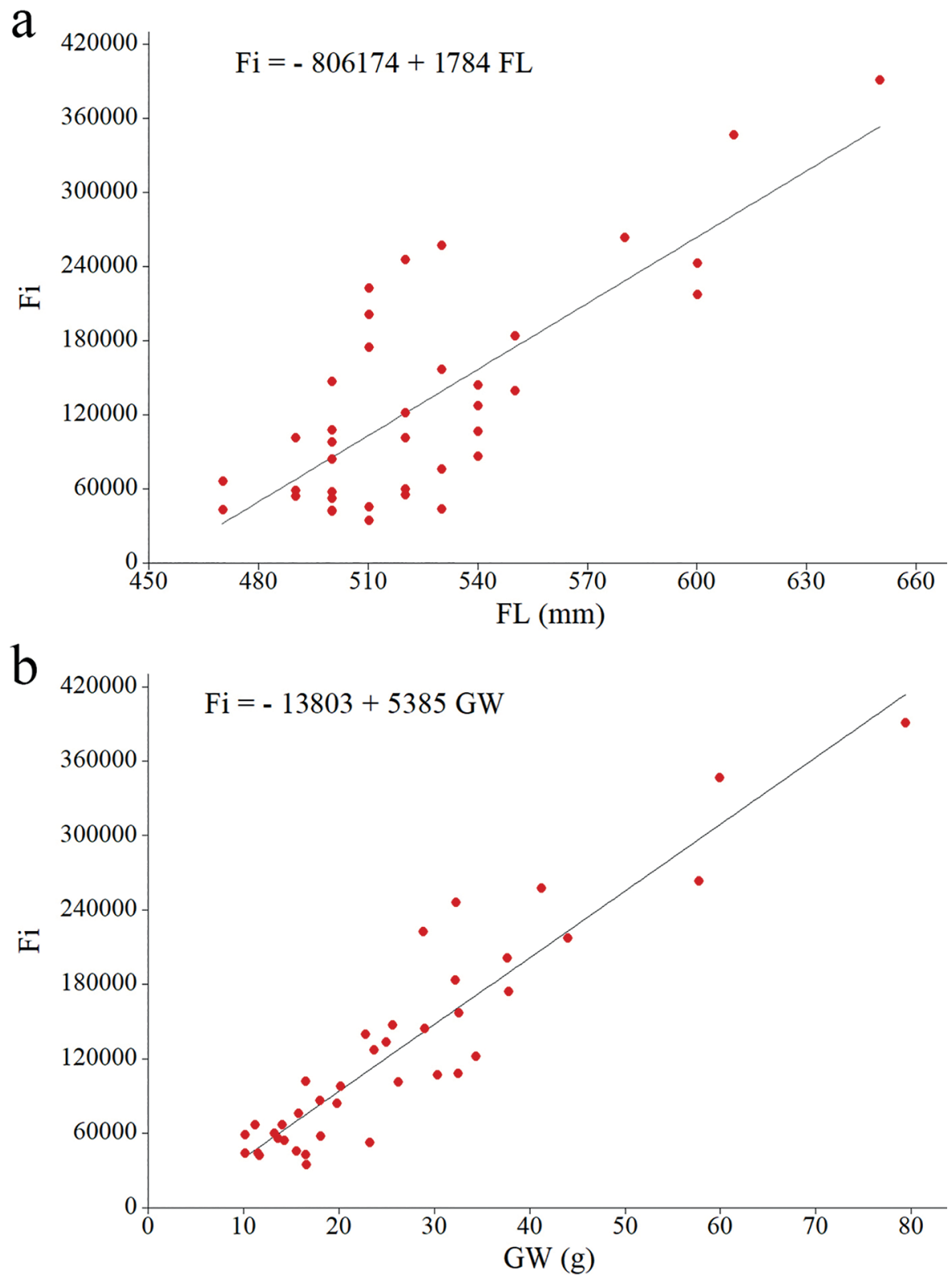

Figure 6. Scomberomorus brasiliensis: regressions between individual fecundity (Fi) and (a) fork length and (b) gonad weight (see also Table 2).

A methodological highlight deserves attention, the efficient use of the gonad-length relationship for spawning period diagnosis. Because of the difficulty in sampling weight data from small-scale fisheries, it was impossible to use the gonadosomatic relationship, i.e., the proportion between the gonad and total body weights (Brown-Peterson et al., 2011). Thus, the gonad index $\left(\mathrm{Gl}=\mathrm{GW} / \mathrm{FL}^{b}, b\right.$ from the length-weight relationship), more often referred to as the gonad condition factor (Vazzoler, 1996), is a good indicator of reproductive activity, mainly for spawning periods (West, 1990; Lowerre-Barbieri et al., 2011). The $\mathrm{Gl}$ denominator implies an estimated value $\left(\mathrm{FL}^{b}\right)$, and it can be calculated using the expected total weight $\left(a \mathrm{FL}^{b}\right)$, becoming the gonadosomatic relationship. Simulated values can be a source of bias, and thus this approach was disregarded. Initially, the size-dependence of the GLR values constituted a problem (West, 1990), which was easily solved adopting a sizeeffect removal procedure (Lombarte and Lleonart, 


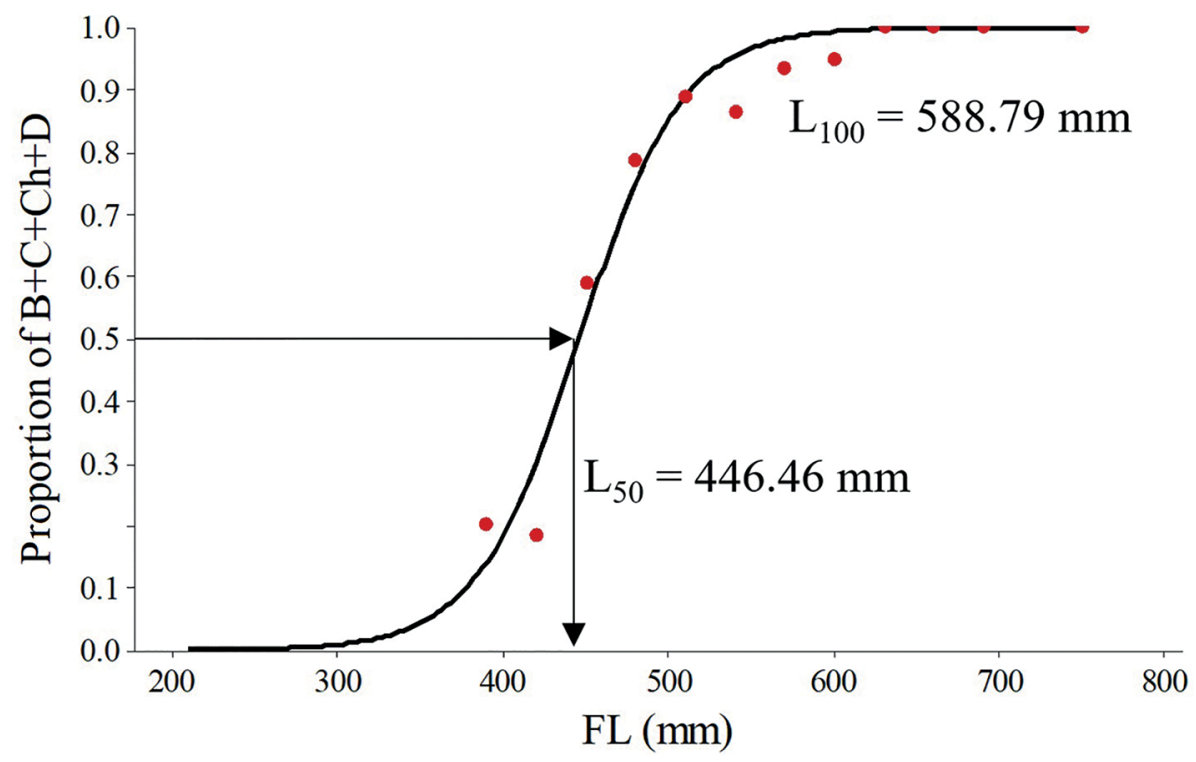

Figure 7. Scomberomorus brasiliensis: mature ogive of females representing average length of first maturity $\left(\mathrm{L}_{50}\right)$ and the length at which all individuals can reproduce $\left(\mathrm{L}_{100}\right)$ (see also Table 2 ).

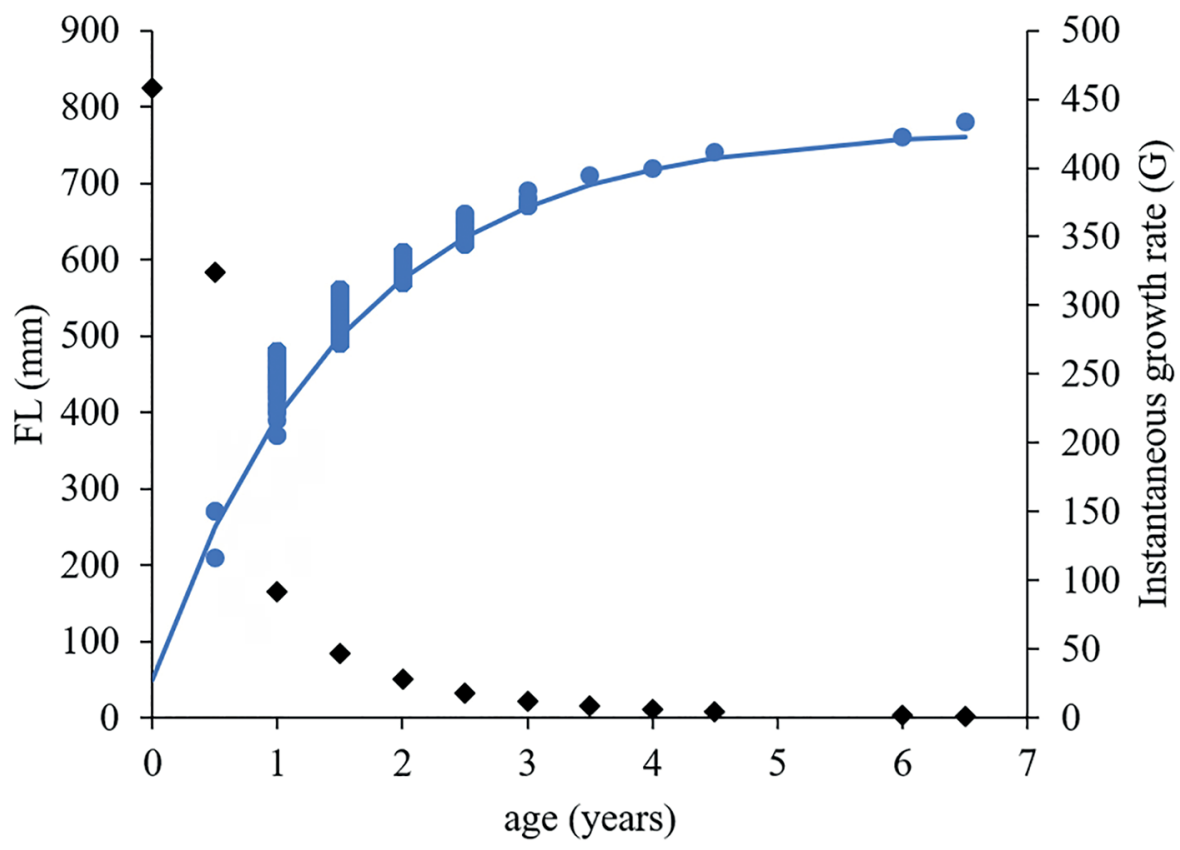

Figure 8. Scomberomorus brasiliensis: von Bertalanffy growth curve $\left(L \infty=771.68 \mathrm{~mm}, k=0.65\right.$ year ${ }^{-1}$ and $t_{0}=-0.102$ year) and fork lengths by age in blue. Black points indicate instantaneous growth rate (G).

1993), efficient for GLR based on the present findings. Thus, the gonad morphological attributes and volume evaluated with the gonad-length relationship indicated an extensive spawning period at the inner continental shelf of $S$. brasiliensis.
Fecundity is an important component of reproductive strategies, operating on a spatial scale related to spawning and nursery areas, and enhancing the reproductive resilience of a stock (Lowerre-Barbieri et al., 2017). For S. brasiliensis, fecundity was higher 
in heavier gonads and larger individuals, as expected. In northeastern Brazil, other estimates include a fecundity of 2,204,000 oocytes, and 350-790 mm $\mathrm{FL}$, which were directly proportional to size, age and weight (Gesteira, 1972), and 871,523 oocytes, and 350-790 mm FL (Lima et al., 2007). More than the features of each stock, differences in relation to the Paraná coast (34,484-390,786, 410-650 mm FL) can be related to period, areas, and the criteria for counting oocytes. The fecundity results are the first referential for southern Brazil, showing the importance of larger and older females in the stock maintenance and other biological and environmental factors (Lowerre-Barbieri et al., 2017).

The average length at first maturity is a tool for stock management, and is usally a referential for establishing minimum legal sizes (LowerreBarbieri, 2009). The current estimate for $S$. brasiliensis (446.46 mm FL corresponding to $524.44 \mathrm{~mm} \mathrm{TL}$ ) was similar to that in most cases in northeastern Brazil. These other estimates include $410 \mathrm{~mm}$ FL (Gesteira and Mesquita, 1976), $419 \mathrm{~mm}$ FL (Nóbrega et al., 2009), 410 mm FL (Lima et al., 2009), and 400 mm FL (Maia et al., 2015). These reveal a conservative pattern for the species in Brazil. In northeastern Brazil, there is an exception of $280 \mathrm{~mm} \mathrm{TL}$, which is a reduction in size due to overfishing (Lima et al., 2007). This last situation highlights the limitations of estimating catches of larger individuals or the use of $\mathrm{L}_{50}$ values to restrict catches as management measures (Chaves, 2012). Especially for S. brasiliensis, larger females have a remarkable contribution to the reproductive success, ensuring egg availability. We refine this diagnostic with age and growth information below.

In northeastern Brazil, previous age and growth parameters of $S$. brasiliensis included values of $\mathrm{L}^{\infty}=1067 \mathrm{~mm} \mathrm{FL}$ and $k=0.16$ year $^{-1}$ (otolith analysis, Ximenes, 1981), $\mathrm{L}_{\infty}=1360 \mathrm{~mm} \mathrm{FL}$ and $k=0.29$ year $^{-1}$ (modal progression analysis, Gonçalves et al., 2003), and $\mathrm{L}_{\infty}=957 \mathrm{~mm} \mathrm{FL}, k=0.15$ year $^{-1}$, and $\mathrm{t}_{0}=-0.212$ years (otolith analysis, Nóbrega and Lessa, 2009). In these studies, age groups varied between one and eight years, matching the present findings. In contrast, the maximum theoretical length $\left(\mathrm{L}_{\infty}=771.68 \mathrm{~mm}\right)$ was lower and the growth rate $\left(k=0.65\right.$ year $\left.{ }^{1}\right)$ was higher than the other estimates. Differences in the results might be due to factors such as the methods applied, size structure with a predominance of juveniles in previous studies, time and area, once the analysis herein applied was properly conducted.

The Powell-Wetherall method is more accurate to estimate $L_{\infty}$ in species that present prolonged spawning and recruitment, a trend that increases the individual variability of growth; in this situation, SLCA method is more accurate for estimating $k$ values (Isaac, 1990). These features apply to S. brasiliensis, and their reproductive biology sustains the present findings regarding age and growth. In the modal progression analysis (SLCA), a new cohort appeared in January, matching the spawning peak identified here. Different cohorts were identified, despite some overlap in the interval of $400-600 \mathrm{~mm}$ FL (modal progression in Supplementary Material). Other elements can affect growth parameter estimation via modal progression analysis. Some species present schools structured by size, not by age (Murie et al., 2012). This probably does not apply to the present samples because, in addition to the absence of larger specimens of $S$. brasiliensis in other fisheries in the area, schools are more typical for juveniles (Maia et al., 2005; Nóbrega and Lessa, 2009), and were not numerous in the present study where adults predominated. Regarding the environmental conditions affecting fish growth, considering the heterogeneity of the inner shelf of the Paraná coast (e.g., water mass, estuaries, and temperatures), it is reasonable to hypothesize that there was growth adaptation for local thermal conditions, resulting in individuals that grow faster than in low latitudes (Yamahira and Conover, 2002). This could explain the higher growth rate value compared to the northeastern Brazil estimates, a question that remains open for future studies.

Thus, the age structure and growth parameters of S. brasiliensis along the Paraná coast reflect its population structure, where it is smaller and grows faster than the stock in northeastern Brazil. Current data on age and growth are robust and suitable, and can reflect the high biological productivity and shelters of the Paraná coast, including its two estuaries (Lana and Bernardino, 2018), which are areas favorable for fish growth as well as spawning, nursery, and feeding. These population patterns have resemblance with the congeneric $S$. queenslandicus, a species that occurs in northern Australia in the same latitude as that of the Paraná coast whose patterns are similar to S. brasiliensis, an example that reinforces the 
results obtained. Scomberomorus queenslandicus is relativelly small $\left(\mathrm{L}_{\infty}\right.$ range $\left.=628-651 \mathrm{~mm}\right)$, grows fast $\left(k\right.$ range $=0.59-0.71$ year $^{-1}$ ) and presents small displacements, with a number of stocks (Begg et al., 1997; Begg \& Sellin, 1998).

Current findings and discussions attained the objectives and confirmed the hypothesis, i.e., along the Paraná coast $S$. brasiliensis has its own biological patterns in terms of size, reproductive biology, age, and growth, constituting a self-sustaining group for management purposes (a stock sensu Cadrin et al., 2014), which is not directly related to that from northeastern Brazil. Based on this, recommendations can be proposed and must be considered in future strategic management planning (Isaac et al., 2013). Juveniles are being preserved, considering their absence in the catches, as are the larger and older individuals, mainly females. A point that deserves attention is the predominance of individuals at one year of age and in first maturity at the landings. If there is a reduction in the resource availability, size reduction, earlier maturation, and other indicators of overfishing, it is recommended a legal-size range for catches, based on the maturity and age structure are provide (Chaves, 2012). Period restrictions of $S$. brasiliensis fishing would be desirable only if larger and older females become constant at landings during spawning periods. It is strongly recommended that all measures enforced emerge from participative management, involving all stakeholders, actors, and processes (Almeida et al., 2007; Mourão et al., 2014), considering the fishing complexity along the Paraná coast (Andriguetto-Filho et al., 2006). For non-English readers, a Portuguese version of this paragraph is available in the Supplementary Material.

\section{CONCLUSIONS}

The importance of S. brasiliensis for the small-scale fishery along the Paraná coast is undeniable, and the present study provided relevant information regarding the population dynamic parameters of this species. The small-scale fishery accesses mainly "young adults", i.e., individuals between 400 - and $650 \mathrm{~mm} \mathrm{FL}$, 1-2.5 years old, in the first maturity stage or just after this stage. Allied to the spawning period and area and growth parameters estimated, they constitute a first referential, standardizing the methods applied to monitor the species in the area. Future changes in these attributes could reliably indicate impacts due to fishing activity or other factors. These biological indicators are essential for proper management (McBride, 2014), highlighting that small-scale fishery is "our best hope for sustainable utilization of coastal resources" (Pauly, 2006).

Further studies focusing on the $S$. brasiliensis stock along the Paraná coast must expand the present analyses. These could comprise: (i) histological analysis of gonads and oocyte diameter concerning the gonad-length relationship, providing additional information regarding the maturation process (West, 1990; Lowerre-Barbieri et al., 2011); (ii) otolith analysis (and/or other calcified structures) to refine age and growth estimates (Vaz-dos-Santos, 2015); (iii) inspection of eggs and larvae in the area (LowerreBarbieri et al., 2017); and (iv) an accurate definition of stock limits and connectivity level among groups in the species distribution area (Cadrin et al., 2014).

\section{ACKNOWLEDGMENTS}

AMVS thanks CNPq for research grant (Process 310451/2018-3) and Dr. Estevan Luiz da Silveira for helping in figures edition. Anonymous referees were essential with their hard comments, helping us to improve the manuscript.

\section{AUTHOR CONTRIBUTIONS}

P.T.C.C.: Conceptualization; Data curation; Formal Analysis; Funding acquisition; Investigation; Methodology; Resources; Supervision; Visualization; Writing - original draft; Writing review \& editing;

P.O.B.: Formal analysis; Investigation; Visualization; Writing - review \& editing;

A.M.V.S.: Formal analysis; Methodology; Validation; Visualization; Writing - original draft; Writing review \& editing.

\section{REFERENCES}

AFONSO, M. G. \& CHAVES, P. T. C. 2021. A pesca de emalhe costeiro de pequena escala no litoral do Paraná: um estudo de caso para a conservação. Biodiversidade e Conservação Marinha, 10, e2021001.

ALMEIDA, Z. S., SILVA, C. M. L., CAVALCANTE, A. N., PAZ, A. C., SANTOS, N. B. \& GONÇALVES, F. S. 2007. Contribuição à conservação e manejo do peixe serra Scomberomorus brasiliensis (Collette, Russo \& Zavala-Camin, 1978) (Osteichtyes, Scombridae) no estado do Maranhão, Brasil. Boletim Técnico-científico do CEPENE, 15(2), 87-97. 
ALVES, D. R. \& LUQUE, J. L. 2006. Ecologia das comunidades de metazoários parasitos de cinco espécies de escombrídeos (Perciformes: Scombridae) do litoral do estado do Rio de Janeiro, Brasil. Revista Brasileira de Parasitologia Veterinária, 15(4), 167-181.

ANDRIGUETTO-FILHO, J. M., CHAVES, P. T. C., SANTOS, C. \& LIBERATI, S. A. 2006. Diagnóstico da pesca no litoral do estado de Paraná. In: ISAAC, V. J., HAIMOVICl, M., MARTINS, A. S. \& ANDRIGUETTO-FILHO, J. M. (orgs.). A pesca marinha e estuarina do Brasil no início do século XXI: recursos, tecnologias, aspectos socioeconômicos e institucionais. Belém: UFPA (Universidade Federal do Paraná).

BATISTA, V. \& FABRÈ, N. N. 2001. Temporal and spatial patterns of serra, Scomberomorus brasiliensis (Teleostei, Scombridae), catches from the fisheries on the Maranhão coast, Brazil. Brazilian Journal of Biology, 61(4), 541-546.

BEGG, G. A., CAMERON, D. S. \& SAWYNOK, W. 1997. Movements and stock structure of school mackerel (Scomberomorus queenslandicus) and spotted mackerel (S. munroi) in Australian east-coast waters. Marine and Freshwater Research, 48(4), 295-301.

BEGG, G. A. \& SELLIN, M. J. 1998. Age and growth of school mackerel (Scomberomorus queenslandicus) and spotted mackerel (S. munroi) in Queensland east-coast waters with implications for stock structure. Marine and Freshwater Research, 49(2), 109-120.

BRASIL. Marinha do Brasil. Centro de Hidrografia da Marinha. 2021. Estações Meteorológicas Convencionais MB - Ilha do $\mathrm{Mel}, 25^{\circ} 30^{\prime} 0^{\prime \prime} S ; 48^{\circ} 19^{\prime} 60^{\prime \prime} W$ [online]. Ilha do Mel: Marinha do Brasil. Available at: http://www.marinha.mil.br/chm/dados-do-smm/estacoes-meteorologicas-convencionais [Accessed: 18 Jan. 2020].

BRITO, C. S. F. D. \& FURTADO-JÚNIOR, I. 2010. Dinâmica sazonal da CPUE da serra, Scomberomorus brasiliensis, capturada com rede de emalhar do tipo serreira no Estado do Pará. Arquivo de Ciências do Mar, 43(1), 88-95.

BROWN-PETERSON, N. J., WYANSKI, D. M., SABORIDO-REY, F. MACEWICZ, B. J. \& LOWERRE-BARBIERI, S. K. 2011. A standardized terminology for describing reproductive development in fishes. Marine and Coastal Fisheries, 3(1), 52-70.

CADIMA, E. L., CARAMELO, A. M., AFONSO-DIAS, M., BARROS, P. C., TANDSTAD, M. O. \& LEIVA-MORENO, J. L. 2005. Sampling methods applied to fisheries science: a manual. Rome: FAO.

CADRIN, S. X., KERR, L. A. \& MARIANI, S. 2014. Stock identification methods: applications in fishery science. $2^{\text {nd }}$ ed. London: Elsevier/Academic Press.

CHAVES, P. T. C. 2012. Tamanho de maturação como instrumento de gestão pesqueira: uma revisão crítica. Acta Biológica Paranaense, 41(3-4), 131-138.

CHAVES, P. T. C. \& ROBERT, M. C. 2003. Boats, gears and procedures of the artisanal fishing at the southern coast of Paraná state, Brazil. Atlântica, 25(1), 53-59.

CHAVES, P.T. C. \& SILVA, A. V. F. 2019. Recursos-alvo que são também bycatch, e recomendação para a gestão da pesca de emalhe no litoral do Paraná, Brasil. Biodiversidade e Conservação Marinha, 8, e2019001.

COLLETTE, B. B., AMORIM, A. F., BOUSTANY, A., CARPENTER, K. E., LEITE JUNIOR., N. O., DI NATALE, A., FOX, W., FREDOU, F. L., GRAVES, J., HAZIN, F. H. V., JORDA, M. J., MINTE-VERA, C., MIYABE, N., NELSON, R., OXENFORD, H., LESSA, R. P. T. \& TRAVASSOS, P. E. 2011. "Scomberomorus brasiliensis". The IUCN Red List of Threatened Species, e.T170335A6753567.
COLLETTE, B. B. \& GRAVES, J. 2019. Tunas and billfishes of the world. Baltimore: Johns Hopkins University Press.

COLLETTE, B. B., RUSSO, J. L. \& ZAVALA-CAMIN, L. A. 1978. Scomberomorus brasiliensis, a new species of Spanish mackerel from the western Atlantic. 1978. Fishery Bulletin, 76(1), 273-279.

EIRAS, J. C., LIMA, J. T. A. X., CRUZ, C. F. \& SARAIVA, A. 2014. A note on the infection of Scomberomorus brasiliensis (Osteichthyes, Scombridae) by Kudoa sp. (Myxozoa: Multivalvulida). Brazilian Journal of Biology, 74(3 Suppl 1), 164-166.

FAO (Food and Agriculture Organization). 1983. FAO species catalogue. Vol.2. Scombrids of the world. An annotated and illustrated catalogue of tunas, mackerels, bonitos and related species known to date. Rome: FAO.

FIGUEIREDO, J. L. \& MENEZES, N. A. 2000. Manual de peixes marinhos do Sudeste do Brasil VI. Teleostei (5). São Paulo: Museu de Zoologia da Universidade de São Paulo.

FONTELES-FILHO, A. A. 1988. Sinopse de informações sobre a cavala, Scomberomorus cavalla (Cuvier) e a serra, Scomberomorus brasiliensis Collette, Russo and Zavala-Camin (Pisces, Scombridae), no Estado do Ceará, Brasil. Arquivo de Ciências do Mar, 27, 21-48.

FRÉON, P., CURY, P., SHANNON, L. \& ROY, C. 2005. Sustainable exploitation of small pelagic fish stocks challenged by environmental and ecosystem changes: a review. Bulletin of Marine Science, 76(2), 385-462.

FRICKE, R., ESCHMEYER, W. N. \& VAN DER LAAN, R. 2020. Eschmeyer's catalog of fishes: genera, species, references [online]. San Francisco: California Academy of Sciences. Available at: http://researcharchive.calacademy.org/research/ichthyology/catalog/ fishcatmain.asp [Accessed: 10 Sep. 2020].

FROESE, R. 2006. Cube law, condition factor and weight-length relationships: history, meta-analysis and recommendations. Journal of Applied Ichthyology, 22(4), 241-253. [Accessed: 01 Aug. 2020]

FROESE, R. \& PAULY, D. 2019. FishBase homepage [online]. FishBase. Available at: http://www.fishbase.org [Accessed: 01 Aug. 2020].

GAYANILO JUNIOR, F. C., SPARRE, P. \& PAULY, D. 2005. FAOICLARM stock assessment tools II. User's guide. Rome: FAO.

GESTEIRA, T. C. V. 1972. Sobre a reprodução e fecundidade da serra, Scomberomorus maculatus (Mitchill), no Estado do Ceará (Brasil). Arquivos de Ciências do Mar, 12(2), 117-122.

GESTEIRA, T. C. V. \& MESQUITA, A. L. L. 1976. Época de reprodução, tamanho e idade na primeira desova da cavala e da serra na costa do Estado do Ceará (Brasil). Arquivos de Ciências do Mar, 16(2), 83-86.

GONÇALVES, A. P., DOURADO, E. C. S., CASTRO, A. C. L. \& TAVARES, R. G. C. F. 2003. Aspectos da dinâmica populacional da serra, Scomberomorus brasiliensis (Teleostei, Scombridae), no estado do Maranhão, Brasil. Boletim do Laboratório de Hidrobiologia, 16(1), 37-46.

HADDON, M. 2011. Modelling and quantitative methods in fishes. $2^{\text {nd }}$ ed. Boca Raton: CRC Press.

HUBERT, W. A., POPE, K. L. \& DETTMERS, J. M. 2012. Passive capture techniques. In: MURPHY, B. R. \& WILLIS, D. W. (eds.). Fisheries techniques. $3^{\text {rd }}$ ed. Bethesda: American Fish Society.

IBAMA (Instituto Brasileiro do Meio Ambiente e dos Recursos Naturais Renováveis). 2007. Estatística da Pesca - Brasil 2007. Brasília: IBAMA/Ministério do Meio Ambiente. 
IBAMA/CEPSUL (Instituto Brasileiro do Meio Ambiente e dos Recursos Naturais Renováveis/Centro de Pesquisa Pesqueira do Sul). 2000. Informe da pesca extrativa marinha em Santa Catarina - 1999. Itajaí: IBAMA/CEPSUL.

ISAAC, V. J. 1990. The accuracy of some length-based methods for fish population studies. Manila: ICLARM Tech.

ISAAC, V. J., ESPÍRITO-SANTO, R. V., BENTES, B. S., MOURÃO, K. R. M. \& LUCENA-FRÉDOU, F. 2013. The Scomberomorus brasiliensis gill-net production system in Northern Brazil; an "invisible" and mismanaged small-scale fishery. In: MOKSNESS, E., DAHL, E. \& STØTTRUP, D. (eds.). Global challenges in integrated coastal zone management. Oxford: John Wiley \& Sons.

JENKINS, G. P., MILWARD, N. E. \& HARTWICK, R. F. 1984. Food of larvae of Spanish mackerels, genus Scomberomorus (Teleostei: Scombridae), in shelf waters of the Great Barrier Reef. Australian Journal of Marine and Freshwater Research, 35(4), 477-482.

LANA, P. C. \& BERNARDINO, A. F. 2018. Brazilian estuaries - $a$ benthic perspective. Basel: Springer.

LEÃO, S. A. S., FURTADO-JÚNIOR, I., ABRUNHOSA, F. A. \& SILVA J. A. 2018. Análise histórica de CPUEs padronizadas da serra Scomberomorus brasiliensis (Pisces: Scombridae) desembarcada no estado do Pará - costa amazônica. Tropical Journal of Fisheries and Aquatic Sciences, 18(1), 23-31.

LEGENDRE, P. \& LEGENDRE, L. 2012. Numerical ecology. $3^{\text {rd }}$ ed. Amsterdan: Elsevier.

LIMA, J. T. A. X., FONTELES FILHO, A. A. \& CHELLAPPA, S. 2007. Biologia reprodutiva da serra, Scomberomorus brasiliensis (Osteichthyes: Scombridae), em águas costeiras do Rio Grande do Norte. Arquivos de Ciências do Mar, 40(1), 24-30.

LIMA, P. R. S., LESSA, R. P. T., CASTRO, A. C. L. \& AZEVEDO, J. W. J. 2009. Tamanho e idade de primeira maturação do serra, Scomberomorus brasiliensis (Osteichthyes; Scombridae Collette Russo \& Zavalla-Camin, 1978) no litoral ocidental do Maranhão - Brasil. Boletim do Laboratório de Hidrobiologia, 22(1), 39-44.

LOPES, P. R. D., OLIVEIRA-SILVA, J. T., ROCHA, A. F. \& FERNANDES, I. P. 2016. Notas sobre a alimentação de Sphyraena guachancho Cuvier, 1829 e Scomberomorus brasiliensis Collette, Russo \& Zavala-Camin, 1978) (Actinopterygii: Sphyraenidae, Scombridae) na praia do Malhado, Ilhéus (Bahia). Revista Mosaicum, 12(24), 69-74.

LOMBARTE, A. \& LLEONART, J. 1993. Otolith size changes related with body growth, habitat depth and temperature. Environmental Biology of Fishes, 37(3), 297-306.

LOWERRE-BARBIERI, S. K. 2009. Reproduction in relation to conservation and exploitation of marine fishes. In: JAMESON, B. G. M. (ed.). Reproductive biology and phylogeny of fishes (agnathans and bony fishes). Enfield: Science Publishers, v. 8B, pp. 371-394.

LOWERRE-BARBIERI, S. K., DECELLES, G., PEPIN, P., CATALÁN, I. A., MUHLING, B., ERISMAN, B., CADRIN, S. X., ALÓS, J., OSPINA-ALVAREZ, A., STACHURA, M. M., TRINGALI, M. D., BURNSED, S.W. \& PARIS, C. B. 2017. Reproductive resilience: a paradigm shift in understanding spawner-recruit systems in exploited marine fish. Fish and Fisheries, 18(2), 285-312.

LOWERRE-BARBIERI, S. K., GANIAS, K., SABORIDO-REY, F., MURUA, H. \& HUNTER, J. R. 2011. Reproductive timing in marine fishes: variability, temporal scales, and methods. Marine and Coastal Fisheries, 3(1), 71-91.
MAIA, R. C. N., SILVA, B. B., HOLANDA, F., PEREIRA, L. J. G. \& ALBERTO, F. C. 2015. Pesca comercial e estrutura populacional da serra, Scomberomorus brasiliensis (Collette, Russo \& Zavala, 1978), desembarcada em um pólo pesqueiro na Costa Norte do Brasil. Biota Amazônia, 5(2), 99-106.

MCBRIDE, R. S. 2014. The continuing role of life history parameters to identify stock structure. In: CADRIN, S. X., KERR, L. A. \& MARIANI, S. (eds.). Stock identification methods: applications in fishery science. $2^{\text {nd }}$ ed. London: Elsevier/Academic Press, pp. 77-96.

MENDONÇA, J. T. \& MIRANDA, L. W. 2008. Estatística pesqueira do litoral sul do estado de São Paulo: subsídios para gestão compartilhada. Pan-American Journal of Aquatic Sciences, 3(3), 152-173.

MENDONÇA, J. T. \& PEREIRA, A. L. C. 2014. Management of gillnet fisheries in the south coast of the state of São Paulo, Brazil. Anais da Academia Brasileira de Ciências, 86(3), 12271237.

MENEZES, M. F. 1970. Alimentação da serra, Scomberomorus maculatus (Mitchill), em águas costeiras do Estado do Ceará. Arquivos de Ciências do Mar, 10(2), 171-176.

MOKSNESS, E., DAHL, E. \& STØTTRUP, D. 2013. Global challenges in integrated coastal zone management. Chichester: Wiley-Blackwell.

MOTULSKY, H. \& CHRISTOPOULOS, A. 2004. Fitting models to biological data using linear and nonlinear regression. Oxford: Oxford University Press.

MOURÃO, K. R. M., ESPÍRITO-SANTO, R. V., SILVA, B. B., ALMEIDA, M. C., ISAAC, V. J., FRÉDOU, T. \& LUCENA-FRÉDOU, F. 2014. A pesca da serra Scomberomorus brasiliensis e alternativas para o seu manejo no litoral nordeste do Pará, Brasil. In: HAIMOVICI, M., ANDRIGUETTO-FILHO, J. M. \& SUNYE, P. S. (orgs.). A pesca marinha e estuarina no Brasil: estudos de caso multidisciplinares. Rio Grande: FURG (Universidade Federal do Rio Grande), pp. 171-180.

MPA (Ministério da Pesca e Aquicultura). 2011. Boletim estatístico da pesca e aquicultura. Brasília: MPA.

MURIE, D. J., PARKYN, D. C. \& DIAMOND, S. L. 2012. Sampling commercial fisheries. In: MURPHY, B. R. \& WILLIS, D. W. (eds.). Fisheries techniques. $3^{\text {rd }}$ ed. Bethesda: American Fisheries Society.

NÓBREGA, M. F., FRÉDOU, F. L., LESSA, R. P. T., HAZIN, F. H. V., OLIVEIRA, P. G. V. \& PINHEIRO, P. B. 2009. Scomberomorus brasiliensis. In: LESSA, R. P. T., BEZERRA JÚNIOR, J. L. \& NÓBREGA, M. F. Dinâmica de populações e avaliação dos estoques dos recursos pesqueiros da Região Nordeste do Brasil. Fortaleza: Martins \& Cordeiro Ltda., v. 5, pp. 64-75.

NÓBREGA, M. F. \& LESSA, R.P.T. 2009. Age and growth of Spanish mackerel (Scomberomorus brasiliensis) off the northeastern coast of Brazil. Neotropical Ichthyology, 7(4), 667-676.

OLIVEIRA, M. R., MORAIS, A. L. S., CARVALHO, M. M., SILVA, A. M., LIMA, J. T. A. X., CHELLAPPA, N. T. \& CHELLAPPA, S. 2015. Estratégias reprodutivas de sete espécies de peixes das águas costeiras do Rio Grande do Norte, Brasil. Holos, 31(6), 107-122.

OLIVEIRA, O. M. B. A. \& SILVA, V. L. 2012. O processo de industrialização do setor pesqueiro e a desestruturação da pesca artesanal no Brasil a partir do Código de Pesca de 1967. Sequência, 65, 329-357.

PAULY, D. 1984. Fish population dynamics in tropical waters: a manual for use with programmable calculators. Manila: ICLARM. 
PAULY, D. 2006. Major trends in small-scale marine fisheries, with emphasis on developing countries, and some implications for the social sciences. Maritime Studies, 4(2), 7-22.

PIOLA, A. R., PALMA, E. D., BIANCHI, A. A., CASTRO, B. M., DOTTORI, M., GUERRERO, R. A., MARRARI, M., MATANO, R. P., MÖLLER, O. O. \& SARACENO, M. 2018. Physical oceanography of the SW Atlantic shelf: a review. In: HOFFMEYER, M. S., SABATINI, M. E., BRANDINI, F. P., CALLIARI, D. L. \& SANTINELLI, N. H. (eds.). Plankton ecology of the Southwestern Atlantic: from the subtropical to the subantarctic realm. Cham: Springer, pp. 574.

PMAP (Projeto de Monitoramento da Atividade Pesqueira no Estado do Paraná). 2020. Banco de dados do monitoramento pesqueiro do Paraná [online]. Paraná: PMAP. Available at: http://propesq-pr.fundepag.br/ [Accessed: 24 Sep. 2020].

PONS, M., MELNYCHUK, M. C. \& HILBORN, R. 2017. Management effectiveness of large pelagic fisheries in the high seas. Fish and Fisheries, 19(2), 260-270.

ROBERT, M. C. \& CHAVES, P. T. 2006. Dynamics of the artisanal fishing activity in two communities on the South Coast of Brazil. Boletim do Instituto de Pesca, 32(1), 15-23.

SHOJI, J., AOYAMA, M., FULIMOTO, H. IWAMOTO, A. \& TANAKA, M. 2002. Susceptibility to starvation by piscivorous Japanese Spanish mackerel Scomberomorus niphonius (Scombridae) larvae at first feeding. Fisheries Science, 68(1), 59-64.

SILVA, G. C., CASTRO, A. C. L. \& GUBIANI, E. A. 2005. Estrutura populacional e indicadores reprodutivos de Scomberomorus brasiliensis Collette, Russo e Zavala-Camin, 1978 (Perciformes: Scombridae) no litoral ocidental maranhense. Acta Scientiarum. Biological Sciences, 27(4), 383-389.
TAGLIAFICO, A., RAGO, N. \& RANGEL, M. S. 2015. Length-weight relationships of 22 commercial fish from Margarita Island, Venezuela. Journal of Research in Biology, 5(3), 1707-1712.

UNIVALI (Universidade do Vale do Itajaí). 2013. Boletim estatístico da pesca industrial de Santa Catarina - Ano 2012. Itajaí: UNIVALI.

VAZ-DOS-SANTOS, A. M. 2015. Otolitos en estudios de edad y crecimiento en peces. In: VOLPEDO, A. V. \& VAZ-DOS-SANTOS, A. M. (eds.). Métodos de estudios con otolitos: principios y aplicaiones. Buenos Aires: CAFP-BA-PIESCI, pp. 303-331.

VAZZOLER, A. E. A. M. 1996. Biologia da reprodução de peixes teleósteos. teoria e prática. Maringá: EDUEM/SBI.

WEST, G. J. 1990. Methods of assessing ovarian development in fishes: a review. Australian Journal of Marine and Freshwater Research, 41(2), 199-222.

XIMENES, M. O. C. 1981. Idade e crescimento da serra, Scomberomorus brasiliensis, no estado do Ceará (Brasil). Arquivo de Ciências do Mar, 21(1-2), 47-54.

YAMAHIRA, K. \& CONOVER, D. O. 2002. Intra- vs. interspecific latitudinal variation in growth: adaptation to temperature or seasonality? Ecology, 83(5), 1252-1262.

ZAR, J. H. 2010. Biostatistical analysis. $5^{\text {th }}$ ed. New Jersey: Prentice-Hall Pearson.

ZUUR, A. F., IENO, E. N., WALKER, N. J., SAVELIEV, A. A. \& SMITH, G. M. 2009. Mixed effects models and extensions in Ecology with $R$. New York: Springer-Verlag. 